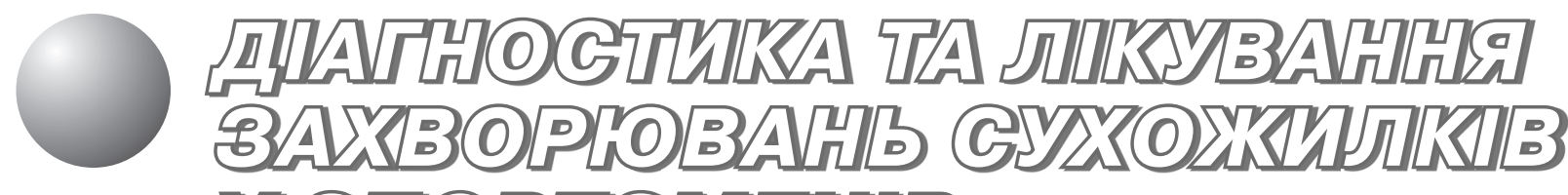 VITIOPTGMEM]B
}

\section{Суперечливі і невирішені питання діагностики і лікування ушкодження сухожилків у спортсменів}

\author{
С. С. Страфун
}

Інститут травматології та ортопедії НАМН України, Київ, Україна

\begin{abstract}
Резюме. Рассмотрены современные взгляды на диагностику и лечение тендинитов различной локализации. Определено, что для лечения данного заболевания оптимальным является применение обогащенной тромбоцитами плазмы в совокупности с массажем и эксцентрическими упражнениями.

Ключевые слова: тендинит, методы диагностики и лечения.
\end{abstract}

Summary. The paper discusses modern views on the diagnosis and treatment of tendinitis in various locations. It is found that the optimal treatment of this disease is the platelet-rich plasma therapy combined with massage and eccentric exercises.

Keywords: tendinitis, methods of diagnosis and treatment.

Клініко-діагностичний алгоритм полягає в клінічному обстеженні. Основний симптом - біль, що виникає при навантаженні м'яза ураженого сухожилка. Для уточнення діагнозу використовують ультразвукове обстеження, що характеризується набряком тканини сухожилка в місці інсерції та в ряді випадків - гіперваскуляризацією. В разі сумніву, місце інсерції знеболюють під ультразвуковим контролем 1 мл $2 \%$-го розчину лідокаїну. Тест вважають позитивним, якщо відсутній специфічний біль при навантаженні.

Сучасні погляди на лікування дегенеративнодистрофрічних уражень полягають у стимуляції репаративно-відновних процесів зміненого сухожилка. Основою для цього $є$ правильні навантаження: відсутність перевантаження з поступовим зростанням рівня навантаження, що приведе до відновлення та регенерації.

Для стимуляції регенерації можна застосовувати допоміжні засоби залежно від важкості процесу - від банального масажу та ексцентричних навантажень, що уже довели ефрективність при лікуванні тендинітів [1], до застосування сучасних методів стимуляції регенерації - ударно-хвильової терапії, збагаченої тромбоцитами плазми та стовбурових клітин, узятих із кісткового мозку або інших джерел, лише в крайньому випадку закінчуючи оперативним втручанням.

Масаж та ексцентричні навантаження ведуть до локального покращення кровообігу та відповідно трофріки ділянки, ураженої гіпоксією.

Ударно-хвильова терапія веде до утворення мікроушкоджень, що запускає каскад гострого запалення, котре призводить до регенерації та покращення структури сухожилка.

Збагачена тромбоцитами плазма (ЗТП) містить як лейкоцити для каскаду запалення, так і тромбоцити, що, вивільняючи фрактори росту, безпосередньо стимулюють неоангіогенез, проліфрерацію як місцевих клітин, так і міграцію та проліферацію стовбурових клітин.

Основним джерелом стовбурових клітин $€$ кістковий мозок або його концентрований пунктат, який містить від 2,5 до 5 млн мононуклеарних лейкоцитів, серед яких знаходяться стовбурові клітини. За допомогою центрифругування 
можна отримати концентрований пунктат, з якого сепарується значна частка плазми та еритроцитів.

Таким чином, концентрований пунктат кісткового мозку містить підвищену, порівняно з кров'ю та ЗТП, кількість мононуклеарів та відповідно стовбурових клітин і концентрат тромбоцитів, які своїми фракторами росту здатні значною мірою покращити проліфрерацію та диференціацію

\section{Література}

1. Alfredson $H$. Heavy-load eccentric calf muscle training for the treatment of chronic Achilles tendinosis / H. Alfredson, стовбурових клітин у місці ушкодження, що приведе до більш ефективного процесу регенерації.

На нашу думку, застосування концентрованого пунктату кісткового мозку є більш ефективним для регенерації, але технічно складнішим у плані отримання, тому оптимальним для лікування тендиніту $€$ застосування багатої тромбоцитами плазми в поєднанні з масажем та ексцентричними вправами.

T. Pietila, P. Jonsson, R. Lorentzon // Am. J. Sports Med. 26(3), 360-366 (1998). 